\title{
Aspects of reproduction associated with the use of a segmented regression to describe the relationship between body weight and shell length of Mytilus edulis
}

\author{
P. N. Salkeld* \\ Plymouth Marine Laboratory, Prospect Place, West Hoe, Plymouth PL1 3DH, United Kingdom
}

\begin{abstract}
Data on total dry tissue weight and shell length were obtained from an intertidal population of Mytilus edulis located in an estuary in SW England. Representation of the $\log _{10}$ transformed data is significantly improved by the use of a segmented regression instead of a single linear regression. There is a significant reduction in the slope $(b)$ of the regression, relating total dry tissue weight $(y)$ to shell length $(x)$, for mussels over $50.3 \mathrm{~mm}$. This pertains also to the component tissues: mantle (at $50.1 \mathrm{~mm}$ shell length), digestive gland (at $60.4 \mathrm{~mm}$ ) and remainder (at $52.7 \mathrm{~mm}$ ). Weight of mantle tissue and of digestive gland does not change $(b \equiv 0)$, whilst remaining tissue increases, but at a reduced rate, as shell length increases in excess of these respective sizes. Stereological examination of sections of mantle tissue were made throughout the year. Results indicate that high levels of reproductive tissue (i.e. $>80 \%$ of mantle volume) are achieved in half as many large individuals (mean shell length $64.7 \mathrm{~mm}$ ) as in 2 smaller size groups (means of 35.1 and $50.4 \mathrm{~mm}$ ). These results suggest that reproductive effort increases to a maximum at a shell length of approximately $50 \mathrm{~mm}$, thereafter declining as size increases. A segmented regression is also appropriate to describe the relationship of total tissue and mantle tissue werght to shell length of a sample from another estuarine population, but not from a wave exposed, open shore population. Reasons for these observations are discussed in the context of the feeding: metabolism ratio, availability of food and age.
\end{abstract}

KEY WORDS: Mussels - Mytilus edulis Size Length Weight A Age Allometry - Reproduction Segmented regression

\section{INTRODUCTION}

Body weight changes in bivalve molluscs are intimately associated with the seasonal cycle of growth, storage/utilisation of reserves and reproduction (Gabbott 1975). In population studies, size (e.g. shell length) is often related to total or component tissue weight by means of linear allometric regressions of the log-transformed data. In studies of Mytilus edulis, this method has been used for both inter- and intra population comparisons of production (Rodhouse et al. 1984, Asmus 1987), and together with estimates of growth, has facilitated the modelling of annual and seasonal growth and reproduction (Bayne \& Worrall 1980, Kautsky

•E-mail: p.salkeld@pml.ac.uk
1982). General reviews of allometry include: Gould (1966), Smith (1980) and Labarbera (1989) and specifically for $M$. edulis, Seed \& Richardson (1990).

In species where age or ontogenetic stage can be identified (e.g. some crustaceans; Teissier 1960, Gould 1966, Aldrich 1974) critical breaks may be used to separate appropriate allometric relationships. In bivalves, particularly Mytilus edulis, whilst it is possible to determine age (Lutz \& Rhoads 1980) and status of reproductive development (Lowe et al. 1982), the cost of so doing may be prohibitive for routine population investigations, so a single linear regression may be imposed that covers the range of sizes being examined. This is often a satisfactory representation - both statistically and historically - but as reviewers such as Smith (1980) and LaBarbera (1989) point out, alternatives are seldom examined. The availability of appro- 
priate software has, however, allowed greater flexibility of analytical procedures. For example, Chappell (1989) describes methods to fit bent lines to data, and Ebert \& Russell (1994) use nonlinear regression to determine the 'point in ontogeny where the development of $y$ begins relative to $x$ '.

Criticisms of the practical use of linear regressions to predict body weights of mussels of a 'standard size' with time have been made by Hilbish (1986). He shows that unless shell growth can be considered to be trivial, the effect of uncoupled growth of shell and tissue may produce substantial errors. Vahl (1985) also questions the suitability of the method when cohort survival, sample size and range may influence regression parameters. Further detractions from the interpretive value of such regressions are the difficulty of separating the effects of size, as distinct from age, on tissue weight, and the assumption that any cause of weight change with time is appropriate, synchronous and proportionate throughout the size range of interest.

Vahl's (1985) concerns about the use of linear allometric regressions arise from his study of a population of Chlamys islandica, where the slopes of regressions of both soma and gonad weight (prior to spawning), against shell height, showed a progressive decline as progressively larger specimens were analysed. He noted a marked decline in gonad output of scallops with shell height greater than 80 to $85 \mathrm{~mm}$, and considered this observation in the context of population dynamics, life history evolution and quantitative reproductive senility (Peterson 1983).

The present paper is concerned with the analysis of shell length and tissue weight data of Mytilus edulis from a population over an annual cycle; it was noted that the slopes of the regressions of log tissue weight on log shell length were consistently reduced if smaller mussels were excluded from the analysis. The similarity to Vahl's (1985) observations are notable, but here, alternatives to the linear regression, in particular a segmented regression model (Chappell 1989), are investigated. This method allows identification of an inflexion in the data if the relationship between tissue weight and shell length changes. Interpretation of the results is discussed in association with reproductive tissue profiles, derived from the stereological examination of the mantles of 3 size groups of these mussels.

\section{MATERIALS AND METHODS}

Mussels of 3 distinct size groups (20 to 25,40 to 45 and 60 to $65 \mathrm{~mm}$ shell length) were collected in June 1983 from the indigenous, intertidal, estuarine population on Beggars Island, situated at the confluence of the Rivers Lynher and Tamar in southwest England.
The mussels were transferred to pairs of cages situated approximately $15 \mathrm{~cm}$ above the substratum, which were positioned at 3 tidal levels, all within the vertical distribution of the natural population and in the same locality.

The cages, measuring $61 \times 61 \times 10 \mathrm{~cm}$ (length $\times$ width $x$ height), were made of plastic-coated wire mesh $\left(12.5 \mathrm{~mm}^{2}\right)$ and were divided internally into 4 equal compartments. Each cage had a hinged lid to allow access for sampling. During $3 \mathrm{~d}$, from 15 to 17 June 1983, 45 individuals of each size group were placed in each compartment of each of the 6 cages. A size range of 48 mussels was collected at the same time to provide data on the initial status of the mussels (Sample 1). Subsequent samples (2 to 10) of each size group were taken from the cages on the following dates: 12 August, (no mid-sized specimens collected), 7 October, 2 December 1983 and 6 February, 17 February, 16 March, 30 March, 13 April and 15 June 1984.

These 'caged' mussels form the major subject of this paper, but to ensure relevance to the undisturbed population, an independent data set (C. M. Worrall unpubl.) is also examined: these samples were taken directly from a central part of the same intertidal mussel bed, over the same period of time and are specifically referred to in the text as 'undisturbed' samples.

In the laboratory, shell length was measured to the nearest $0.1 \mathrm{~mm}$ using vernier calipers; body tissues were removed from their shells and the wet weights of the digestive gland (with the exception of the 2 March samples), mantle tissue and remainder were determined. A weighed piece of mantle was taken from a representative sample $(n \approx 30)$ of each size group and fixed in Baker's formol calcium. This was used for subsequent stereological assessment of the quantity of reproductive tissue; all the other tissues were placed together in a preweighed vial and freeze-dried. The dry weight of the 'undisturbed' mussel tissues was determined after drying in an oven at $80^{\circ} \mathrm{C}$ to constant weight. Where appropriate, the ratio of wet to dry weight for each individual was used to compensate for the small quantity of mantle tissue removed. Dry weights of the mantle, digestive gland and remainder were determined from the ratios of their respective wet weights.

The standard allometric regression equation was used to relate tissue dry weight $y(\mathrm{~g})$ to shell length $x(\mathrm{~mm})$ :

$$
\log _{10} y=\log _{10} a+b \log _{10} x
$$

where $a$ and $b$ are the fitted intercept and slope respectively. Statistical analyses, fitting of linear and nonlinear regressions and graphic illustrations were performed using SAS (SAS Institute Inc. 1985a, b) procedures.

The stereological analysis of the fixed mantle tissue followed the methods of Lowe et al. (1982), but here. 
only the percentage volume fraction of reproductive tissue (this includes gametogenic cells and gametes at all stages of development) is recorded. Males and females were analysed together because there is no evidence to suggest differences in their gamete output, mantle weights, timing of gametogenesis or spawning (Sprung 1983, Okamura 1986 and author's unpubl. obs.j. The sections of mantle tissue used for this analysis were only identified to the level of size group: determination of the total weight of reproductive tissue per individual was therefore not possible.

A further sample of mussels was taken from this Lynher site, and 2 other intertidal populations situated on the south coast of Devon, UK, on 3 consecutive days (4 to 6 February 1992): Whitsand (exposed rocky shore, size range 19.9 to $77.2 \mathrm{~mm}$ shell length), Exmouth (estuary, 22.1 to $66.3 \mathrm{~mm}$, mussel bed No. 30; see McGrorty \& Goss-Custard 1991) and Lynher (estuary, 18.0 to $76.0 \mathrm{~mm}$ ) respectively. Shell lengths were measured, and the dry weights of total tissue and mantle tissue were determined by oven-drying the separated tissues to constant weight at $80^{\circ} \mathrm{C}$.

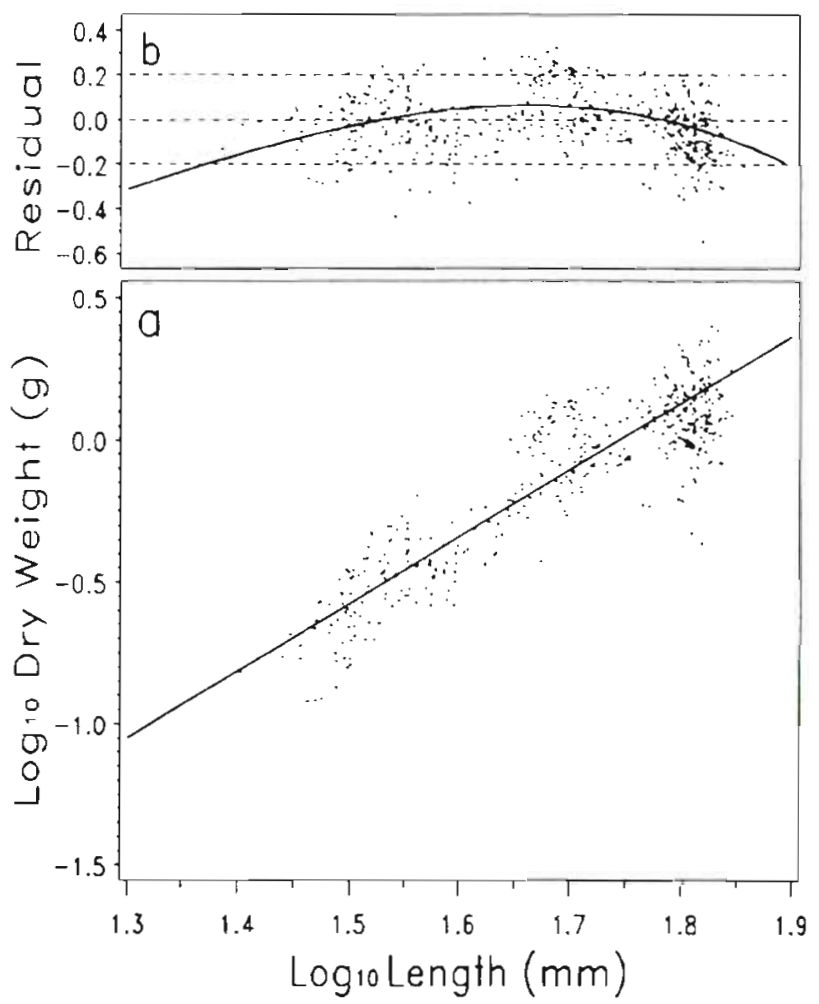

Fig. 1. Mytilus edulis. (a) Scatter plot, with fitted linear regression, of ( $\log _{10}$ transformed) total dry tissue weight, against shell length, for samples $2-4,6,9$ and $10(n=498)$. (b) The residuals, from the linear regression, plotted against $\log _{10}$ shell length $(\mathrm{mm})$. Asymmetry, with respect to a residual value of 0 , is highlighted by the horizontals and the fitted cubic regression

\section{RESULTS}

\section{Whole body weight}

In order to represent the overall relationship between total tissue dry weight (TDW) (g), and shell length (Len) ( $\mathrm{mm}$ ) for the experimental period, an equal number (83) of data pairs were randomly selected from samples 2-4, 6, 9 and 10 (collected at intervals of approximately $2 \mathrm{mo}$ ). A standard linear regression was used to fit the data after $\log _{10}$ transformation. The following equation (with $95 \%$ confidence limits in parentheses) was calculated:

$$
\begin{gathered}
\log _{10} \text { TDW }=-4.11( \pm 0.181)+2.35( \pm 0.108) \log _{10} \text { Len } \\
(\mathrm{n}=498)
\end{gathered}
$$

This single linear regression, however, did not produce a visually acceptable fit to the data (Fig. 1a), despite being highly significant $(\mathrm{p}<0.001)$ with a correlation coefficient $\left(R^{2}\right)$ of 0.79 . The asymmetry, defined by the shape of a fitted cubic regression to a plot of the residuals against $\log _{10}$ length (Fig. $1 \mathrm{~b}$ ), was

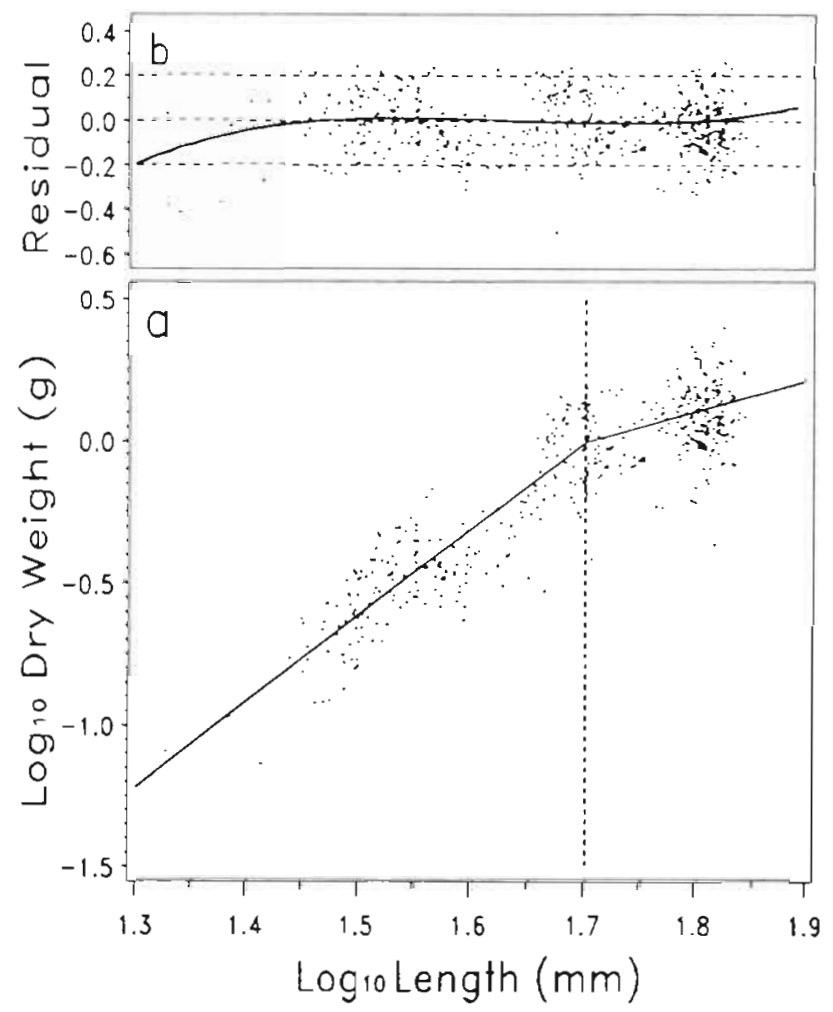

Fig. 2. Mytilus edulis. (a) Scatter plot of the same data as in Fig. 1. Here, 2 regressions, joined at an inflexion point (segmented regression), are fitted. The location of the inflexion on the length axis is shown by the perpendicular at 1.702 $(5.03 \mathrm{~mm})$. (b) The residuals, obtained by fitting the segmented regression, plotted against $\log _{10}$ shell length (mm). The scatter, and the fit of a cubic regression, should be compared to that in Fig. 1b 
taken as confirmation of a poor fit. The data were reanalysed to incorporate 2 contiguous straight lines, joined at an inflexion point (Chappell 1989). The SAS Procedure NLIN (SAS Institute Inc. 1985a) was used to determine the best fit, and location of the inflexion, by the method of least squares. This provided a better fit (Fig. 2a) with a more balanced plot of the residuals (Fig. 2b); the correlation coefficient was marginally improved to 0.81 and the confidence limits increased substantially, but the significant reduction in the residual sum of squares from 11.60 to $10.20\left(F_{2,494}=33.90\right.$, $p<0.001$ ), confirmed the acceptability of this method of data analysis. The equations of the 2 regression lines were:

Lower segment regression:

$\log _{t 0}$ TDW $=-5.13( \pm 0.380)+3.01( \pm 0.222) \log _{10}$ Len

Upper segment regression:

$\log _{10}$ TDW $=-1.88( \pm 0.711)+1.10( \pm 0.437) \log _{10}$ Len

The point of inflexion on the length axis was 1.70 $( \pm 0.028)$ or $50.3 \mathrm{~mm}(+3.36 /-3.16)$ (Fig. 2a).

To confirm that the data had not been the subject of an unknown bias, the analysis was repeated on independent data (Worrall unpubl.), derived from the 'undisturbed' mussels of the same size range (19.25 to $71.85 \mathrm{~mm}$ ). The equivalent single regression was:

$$
\begin{gathered}
\log _{10} \text { TDW }=-5.00( \pm 0.271)+2.89( \pm 0.166) \log _{10} \text { Len } \\
(\mathrm{n}=152)
\end{gathered}
$$

The 2 contiguous regressions were:

Lower segment regression:

$$
\log _{10} \text { TDW }=-6.27( \pm 0.468)+3.75( \pm 0.284) \log _{10} \text { Len }
$$

Upper segment regression:

$$
\log _{10} \text { TDW }=-1.97( \pm 0.876)+1.17( \pm 0.550) \log _{10} \text { Len }
$$

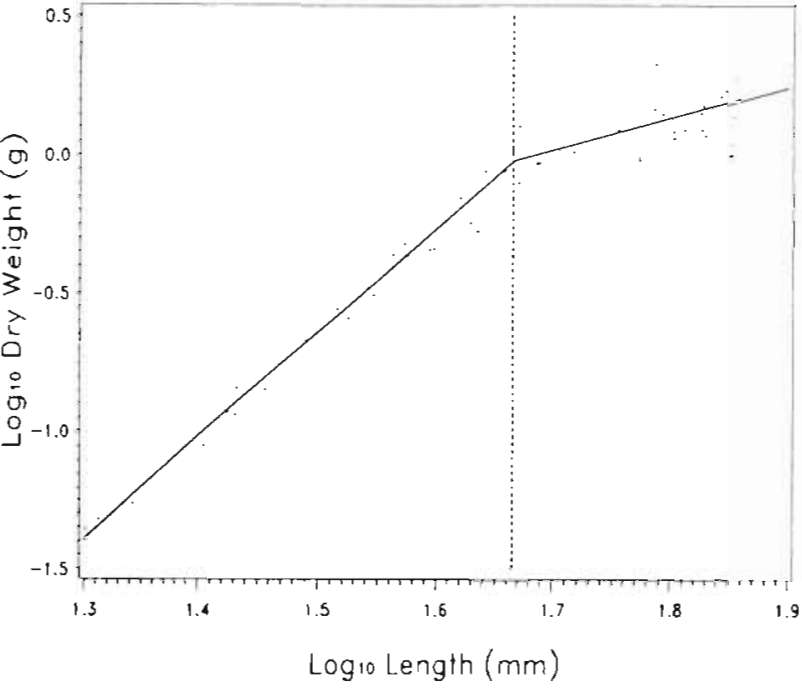

Fig. 3. Mytilus edulis. A segmented regression fitted to $\left(\log _{10}\right)$ weight-length data obtained from undisturbed mussels (Worrall unpubl.; see text and Table 2$\}(n=152)$. The inflexion is located on the length axis at $1.665(46.2 \mathrm{~mm})$ (cf. Fig. 2a)

The residual sum of squares was again significantly reduced from 4.16 to $2.74\left(F_{2,148}=40.9, \mathrm{p}<0.001\right)$. The point of inflexion was $1.665( \pm 0.033)$ or $46.2 \mathrm{~mm}$ $(+3.62 /-3.44)$ (Fig. 3). This is taken as confirmation that a distinct change in the relationship between tissue weight and shell length occurs when these mussels, whether caged or undisturbed, reach a length of approximately $50 \mathrm{~mm}$.

The use of a curve to represent the distribution of the 'caged' data was also considered, however both quadratic and cubic regressions produced residual sums of squares greater than that of the segmented regression.
Table 1. Mytilus edulis. Data means of total tissue dry weight, for 10 selected shell lengths $( \pm 1 \mathrm{~mm})$. The deviation between these and the calculated estimates from the linear and segmented regressions [see Table 2, total tissue (caged)] are expressed as percentages

\begin{tabular}{|cccccc|}
\hline $\begin{array}{c}\text { Shell } \\
\text { length } \\
(\mathrm{mm})\end{array}$ & $\begin{array}{c}\text { Data } \\
\text { mean } \\
(\mathrm{g})\end{array}$ & $\begin{array}{c}\text { Linear regression } \\
\text { Estimate } \\
(\mathrm{g})\end{array}$ & $\begin{array}{c}\text { Deviation } \\
(\%)\end{array}$ & $\begin{array}{c}\text { Segmented regressions } \\
\text { Estimate } \\
(\mathrm{g})\end{array}$ & $\begin{array}{c}\text { Deviation } \\
(\%)\end{array}$ \\
\hline 25 & 0.12 & 0.15 & +25.0 & 0.12 & 0.0 \\
30 & 0.21 & 0.23 & +9.5 & 0.21 & 0.0 \\
35 & 0.38 & 0.33 & -13.2 & 0.33 & -13.2 \\
40 & 0.39 & 0.45 & +15.4 & 0.49 & +25.6 \\
45 & 0.73 & 0.60 & -16.4 & 0.70 & -4.1 \\
50 & 1.04 & 0.76 & -26.9 & 0.96 & -7.7 \\
55 & 1.08 & 0.95 & -12.0 & 1.08 & 0.0 \\
60 & 1.29 & 1.17 & -9.3 & 1.19 & -7.8 \\
65 & 1.28 & 1.41 & +10.2 & 1.30 & +1.6 \\
70 & 1.53 & 1.68 & +9.8 & 1.41 & -7.8 \\
& & & & \\
Median absolute deviation & & & & \\
\end{tabular}

\section{Comparison of whole dry tissue weight estimation}

In Table 1 , both the linear and the pair of segmented regressions are used to calculate the total dry tissue weight of mussels of a sequence of 10 different 'standard' shell lengths. The mean dry weight of individuals of the same shell lengths $( \pm 1 \mathrm{~mm}$ ) extracted from the data, are then compared with the 2 calculated estimates; the deviation is expressed as a percentage. The median absolute deviation of these 10 estimates is significantly reduced from 12.6 for the linear regression estimates to 5.9 for the inflexed regression estimates (Mann-Whitney test, $p<0.01$ ). 


\section{Mantle tissue, digestive gland and remaining tissue}

The relationship of the $\log _{10}$ dry weight of 2 component organs, mantle and digestive gland, and $\log _{10}$ shell length (caged mussels), were investigated as described above. In both cases a significant reduction in residual sum of squares can be achieved with a segmented regression. The data are summarised in Table 2. The length coordinates of the inflexion points are significantly different for these 2 organs. Whilst the slope $(b)$ of the upper segment regression is negative for the mantle (Fig. 4) and positive for the digestive gland, they are not significantly different from zero; the analysis of the mantle of the undisturbed mussels also shows a (nonsignificant) negative slope for the upper segment regression.

These 2 organs are important in the storage and gametogenic cycle of Mytilus edulis (Thompson et al. 1974). By excluding both these reproductive factors, it is possible to examine whether the remaining tissue weight (not the true somatic tissue, as it contains some invasive reproductive tissue; $D$. Lowe pers. comm.) is also better represented by a single or segmented regression with respect to shell length. The results are presented in Table 2, showing that this tissue also contributes to the nonlinearity of the total weight-length relationship, but contrasts in that the upper segment has a significant positive slope ( $b=1.55 \pm 0.369)$.

\section{Seasonal changes in body weight}

The above analyses are concerned with the combined data from 6 of the samples $(2-4,6,9$ and 10) col-

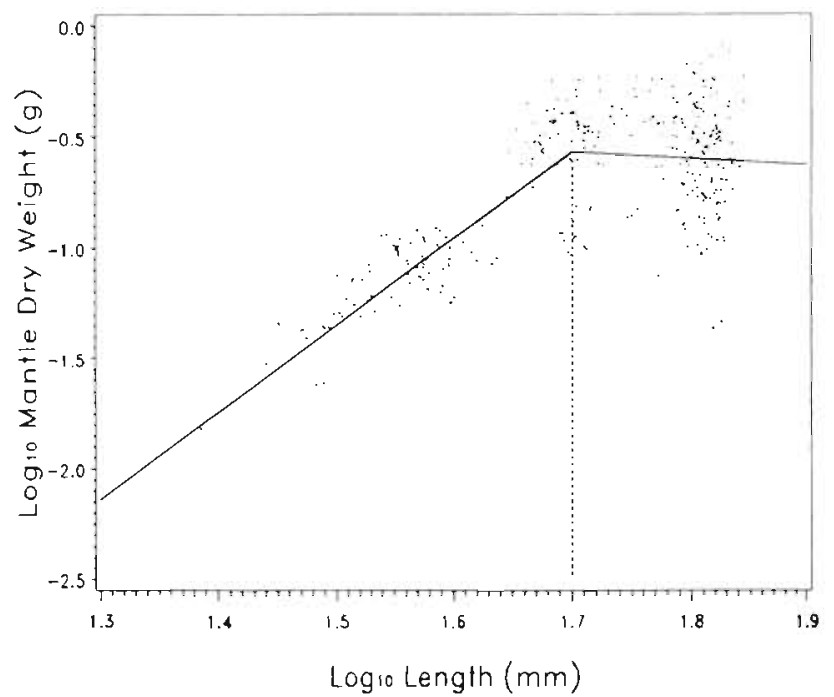

Fig. 4. Mytilus edulis. A segmented regression fitted to $\left(\log _{10}\right)$ mantle weight-shell length data obtained from the caged mussels. The upper segment has a negative slope and the inflexion is located on the length axis at $1.70(50.1 \mathrm{~mm})$ (see Table 2)

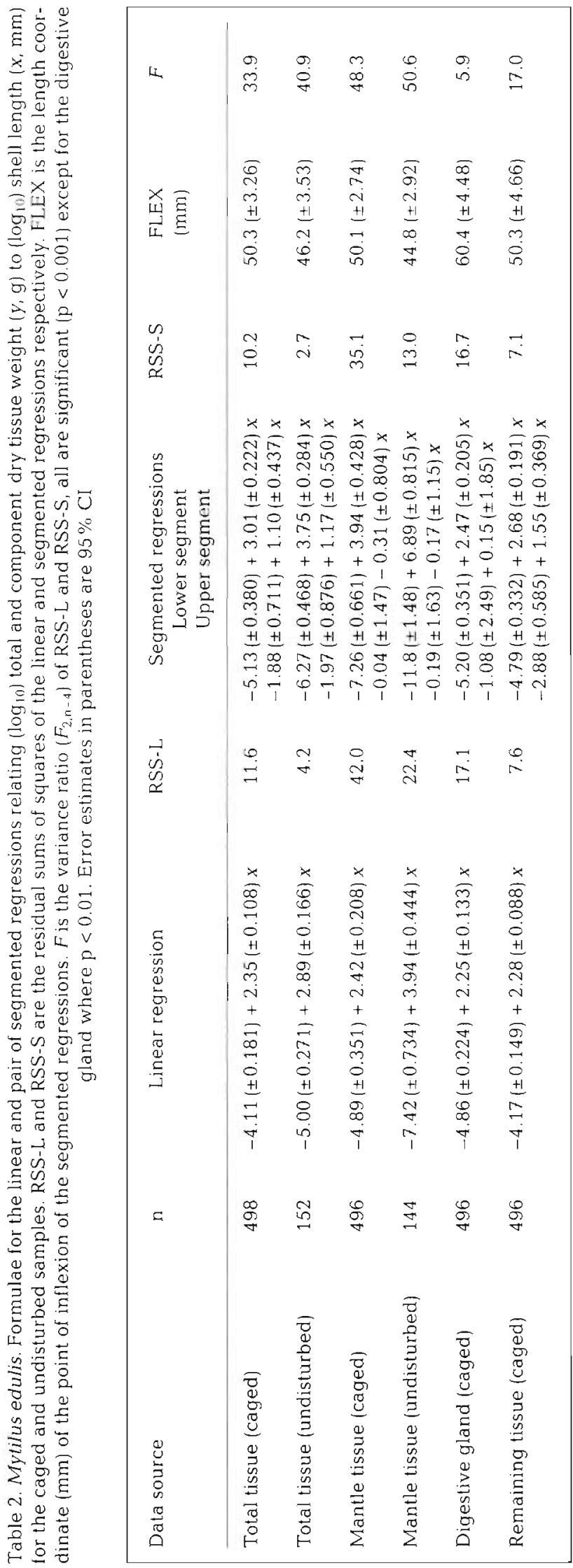




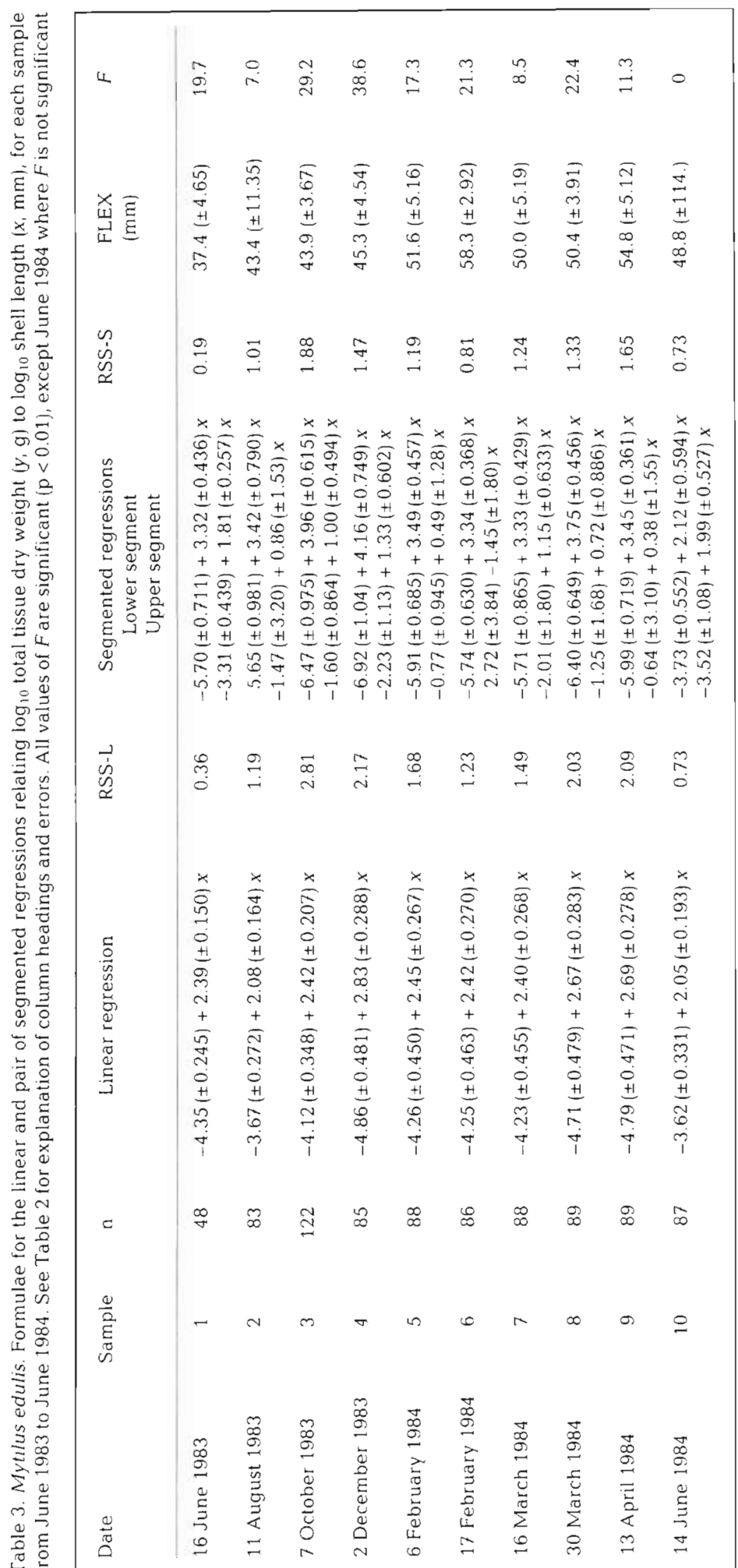

lected between June 1983 and June 1984. To investigate whether a seasonal aspect to this phenomenon could be discerned, the same analytical approach was used on whole tissue weight data from each of the 10 individual samples.

Compared to a single regression, a significant reduction in residual sum of squares can be achieved by fitting a segmented regression to 9 of the 10 data sets. These analyses are presented in Table 3, and illustrated 3-dimensionally in Fig. 5. In June 1984, there was no difference between the residual sum of squares of the linear and segmented regression; for the remainder of the year, the evidence for nonlinearity is substantial. The estimated length where the inflexion occurs (excluding June 1984) varies from 37.4 to $58.3 \mathrm{~mm}$ with a mean of $48.3 \mathrm{~mm}$ (SD 6.44). The notable high value of $58.3 \mathrm{~mm}$ occurs in the 17 February sample; it coincides with a substantial decline in the weight of the largest sizes, with a negative slope for the upper regression ('upper segment' in Table 3). Such a dramatic decline in body weight is probably associated with loss of gametes (see below), and it is of interest to note that this occurs at a different time $(30$ March to 13 April) for individuals of the smallest size.

\section{Gametogenic analysis}

Five fields of each mantle section were examined microscopically from a total of 281 small, 245 medium and 261 large mussels with shell length means $( \pm \mathrm{SD})$ of $35.1( \pm 5.0), 50.4( \pm 4.8)$ and $64.8( \pm 2.8) \mathrm{mm}$ respectively. The quantity of reproductive tissue (gametogenic tissue and gametes at all stages of development), in each of the mantle sections, is expressed as the mean percentage volume fraction (\% GVF) (Lowe et al. 1982). Reproductive tissue profiles (Fig. 6a to c) are used to illustrate the quantity of this tissue, as it varies with time, in the 3 size groups during the experimental period. For each sampling occasion the percentage 


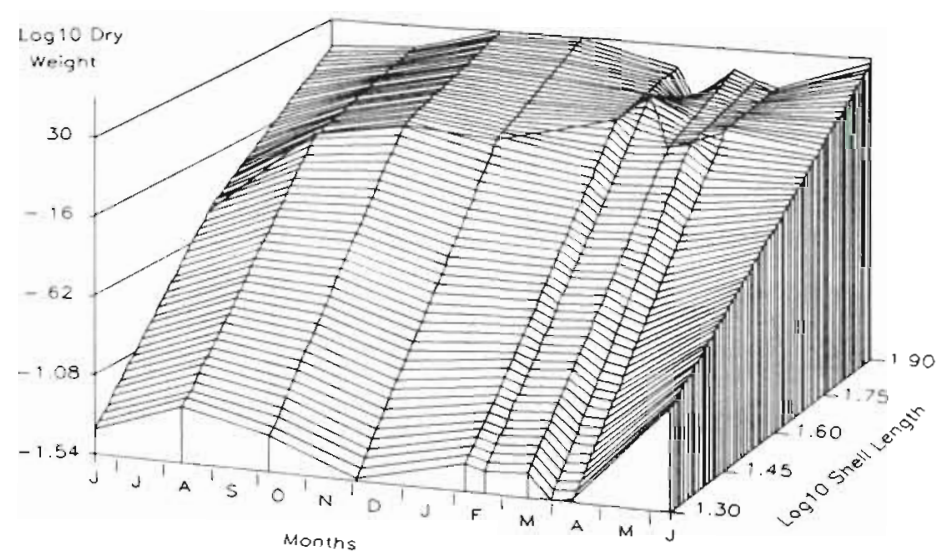

Fig. 5. Mytilus edulis. lllustration of the 9 segmented regressions (June 1983 to April 1984) and linear regression (June 1984) presented in Table 3 , relating $(y)\left[\log _{10}\right.$ dry tissue weight $\left.(g)\right]$, to $(x)\left[\log _{10}\right.$ shell length $(\mathrm{mm})$ ]. The regression lines are connected laterally at regular intervals to highlight the changes between them; the inflexion points, between the upper and lower pairs of each segmented regression, are also connected laterally

frequency of individuals occupying each $20 \%$ GVF interval (illustrated with 5 grades of hatching intensity) is plotted cumulatively on the vertical axes; on the horizontal axes, the vertical dividing lines represent the mid-point between each consecutive sample, and the boundaries are located at the time of the first and last sample dates (the data include the August samples for the small (Fig. 6a) and large (Fig. 6c) sizes; a key is inserted where data are missing for the medium size [Fig. 6b)].

The figure shows that: (1) during the months of major gametogenic activity (February to April, samples 5 to 9), the proportion of all mussels examined, in each size group, that have more than $80 \%$ reproductive tissue in their mantle are: $50.7 \%$ (small), $44.8 \%$ (medium) and $24.2 \%$ (large); and (2) for the remainder of the year (June to December, samples 1 to 4 and 10) the quantity of reproductive tissue is much lower, but increases with size. Thus the proportions of these mussels with the minimal quantity of reproductive tissue $(<20 \%)$ in their mantles are: $90.8 \%$ (small), $70.3 \%$ (medium) and $62.8 \%$ (large)

These same data (excluding all August data) are displayed in Fig. 7a (small), b (medium) and $c$ (large) as frequency histograms. Whilst the overall \% GVF is shown for each size group, the distribution of the data cannot be described with summary statistics. An analysis of the (cumulative) distributions (Kolmogorov-Smirnov 2-sample test) indicates that the data from the large mussels differs significantly from the other 2 sizes $(p<0.01)$, whilst the small and medium sizes are not significantly different $(p>0.05)$. In order to identify the location of these differences, the absolute frequency of mussels in each $20 \%$ GVF interval is compared for each size group with a chi-squared test; this confirmed the results of the Kolmogorov-Smirnov test, and of all the 15 paired comparisons ( 3 sizes, 5 intervals) only 3 were significantly different $(p<0.05)$. Thus, there are fewer small mussels in the 20 to $40 \%$ GVF category than large mussels - explained by the greater synchrony of reproductive tissue production in the smallest size group (Fig. 6), and that half as many large mussels achieve more than $80 \%$ reproductive tissue in their mantles as small and medium sized specimens (Fig. 6).

\section{Population comparison}

The relationship between $\log _{10}$ dry tissue weight (total and mantle) and $\log _{10}$ shell length for the 3 populations, sampled in February 1992, was investigated as described above, the results are presented in Table 4

No significant reduction of residual sum of squares can be achieved with a segmented regression compared to a single linear regression between tissue weight (total and mantle) and shell length for the Whitsand sample. For the Lynher and Exmouth data (both tissues), there is, however, a significant ( $p<0.001$ ) reduction of residual sum of squares; the location of the inflexion is different for the 2 populations, but is not different for the 2 tissue categories within the populations (overlapping $95 \%$ confidence intervals).

\section{DISCUSSION}

These data provide evidence that substantial nonlinearity in the relationship between $\log _{10}$-transformed dry tissue weight and shell length of Mytilus edulis can occur. Use of 2 contiguous allometric regressions, a segmented regression (Chappell 1989), can significantly reduce the associated residual sum of squares when compared with that obtained with a single linear regression, and so improve the representational quality of the model (Table 1). This is found in 3 sets of data: the first from caged mussels; the second from the undisturbed mussels from the same population at the same time; and the third from 2 of 3 separate population samples (Tables 2,3 \& 4).

Other examples of a change in the relationship between body weight and shell size, within a discrete population of mytilid bivalves, can be found in the literature. Illustrations of data in Seed (1973, Fig. 2) and 


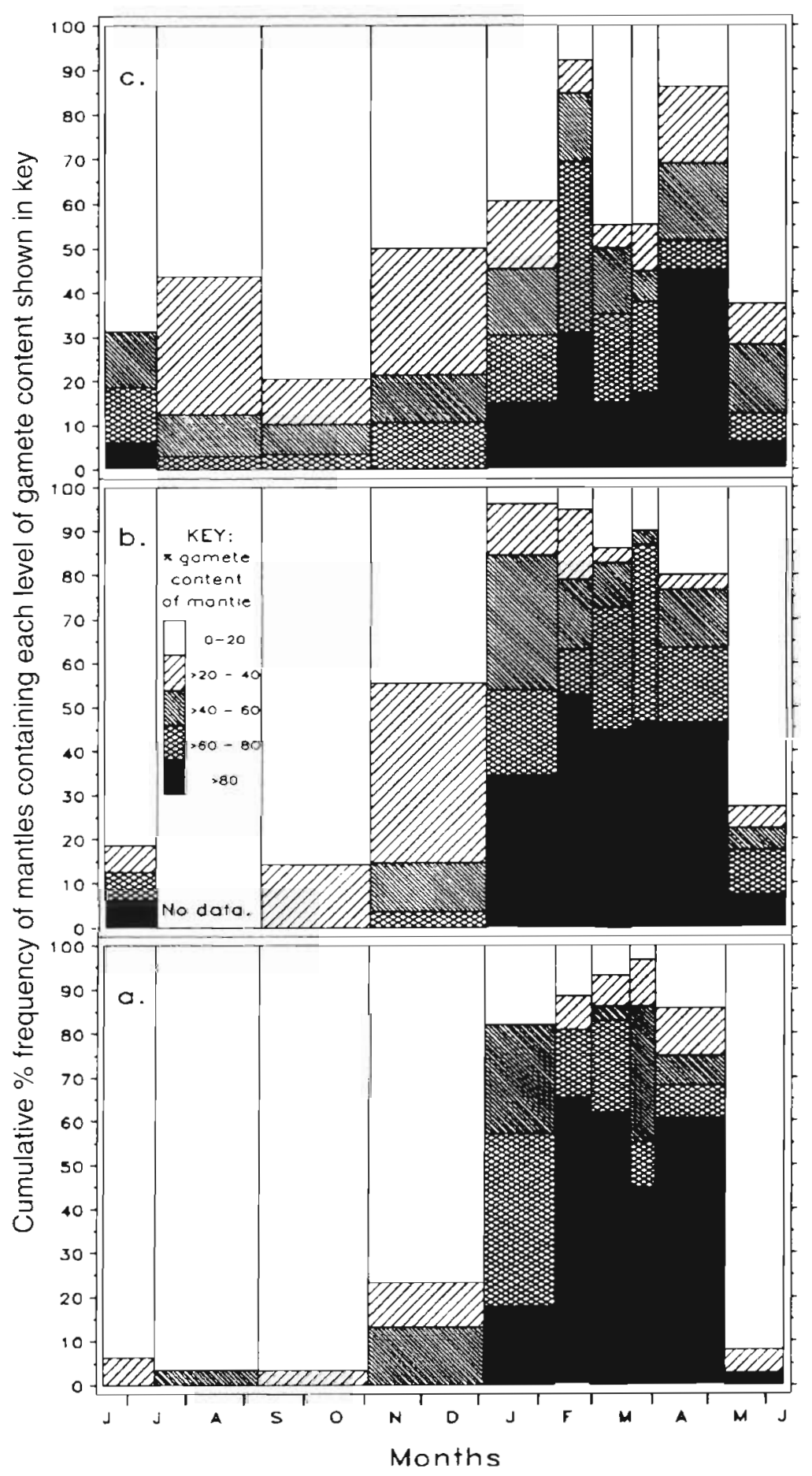

Fig. 6. Mytilus edulis. Reproductive tissue profiles from the stereological examination of the mantles of 3 sizes of mussels: (a) small (shell length $35.1 \mathrm{~mm} \pm 5.0$ (SD), $\mathrm{n}=281$.), (b) medium (50.4 mm $\pm 4.8, \mathrm{n}=245$ ) and (c) large (64.8 $\mathrm{mm} \pm 2.8, \mathrm{n}=261)$. The proportion of tissue in edch mantle containing gametogenic cells and gametes, at all stages of development (\% GVF), is allocated to 1 of 5 levels (see key in b): the percentage of mussels in each level is then plotted cumulatively on the $y$-axis. The verticals represent the mid-point between each sample collection, the boundaries are located at the time of the first and last collection dates
Dare [1976, Figs. 13(A) \& 14(A)] suggest reduced tissue weight for mussels in excess of approximately 30 to $40 \mathrm{~mm}$. Theisen (1968), working with a very wide size range ( 6 to $86 \mathrm{~mm}$ ) of cultivated mussels from the Danish Wadden Sea, notes the opposite case - an increase in slope at a shell length of $45 \mathrm{~mm}$. Hosomi (1985), with a similar size range of the closely related $M$. galloprovincialis, identified a specific length $(15 \mathrm{~mm})$ where the slope decreases. Similarly Kuenzler (1961) related the cube root of body weight to shell height of the mussel Modiolus (= Geukensia) demissa and observed an inflexion at $25 \mathrm{~mm}$ (length equivalent $=62.5 \mathrm{~mm}$ ); he suggests the onset of sexual maturity as the cause. But the data presented here locate the inflexion at a size well beyond such a stage [reproduction commences at $<10 \mathrm{~mm}$ shell length in the Lynher population; Lowe pers. comm.; see also Sprung (1983) for comparisons of the size at which reproductive activity commences in Mytilus edulis].

When the weights of the 3 component tissues of the caged mussels - mantle, digestive gland and remaining tissue - are analysed, they all demonstrate the inflexed relationship observed in the whole tissues (Table 2). The reproductive tissue (mantle) shows the most marked degree of inflexion: from $b=3.94$ for the lower regression, to $b=-0.31$ for the upper; the undisturbed mussels have an even greater difference. The digestive gland and remainder show less difference between the slopes of the lower and upper segment regressions. When the observation on the mantle is considered alongside the stereological analysis of this tissue (Figs. 6\& 7), then it is concluded that, unless there is a change in the quality of the gametes, the weight-specific reproductive potential declines in the population as size increases beyond a shell length of approximately $50 \mathrm{~mm}$.

Such a conclusion is not only significant because of its possible effects on the population dynamics of mussels, but also because it contrasts with much previous work that records or estimates reproductive output to increase with size as the energy required for growth declines (Thompson 1979, Bayne \& Worrall 1980. 


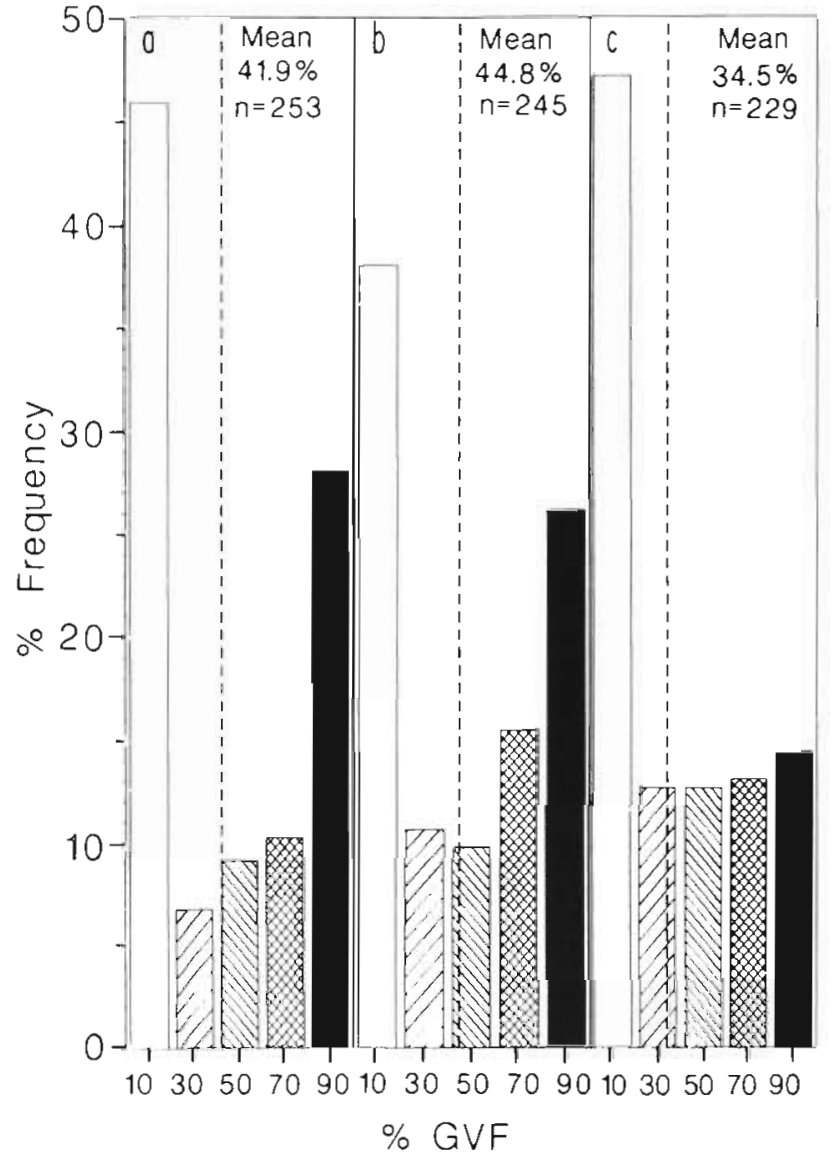

Fig. 7 Mytilus edulis. Percentage frequency of 5 levels (see Fig. 6b for key to hatching intensity) of percentage reproductive tissue volume fraction (\% GVF) in 3 size groups: (a) small (shell length $35.1 \mathrm{~mm} \pm 5.0$ (SD), (b) medium (50.4 $\mathrm{mm} \pm 4.8$ ) and (c) large $(64.8 \mathrm{~mm} \pm 2.8)$

Kautsky 1982, Bayne \& Newell 1983, Bayne et al. 1983, Sprung 1983, Thompson 1984). That this conclusion can be extended to other populations (and times) is supported by the apparent inflexion in the data of Seed (1973) and Dare (1976), and in 2 of the 3 population samples (Table 4). These findings are discussed in relation to 3 of the most important factors that determine growth and reproduction - feeding rate, food availability and age.

The lower than expected weight, due primarily to the marked reduction in the exponent $(b)$ of the mantle tissue weight, suggests that larger mussels (approximately $>50 \mathrm{~mm}$ ) are at a nutritional disadvantage compared to smaller ones. In physiological terms this is the case, because in previous studies of this and other populations (Vahl 1973, Bayne et al. 1976, Jørgensen 1976 , Bayne \& Widdows 1978, and Bayne \& Newell 1983 for review) the exponent relating body weight to feeding rate (energy gain) was found to be significantly lower than the exponent relating body weight to metabolic

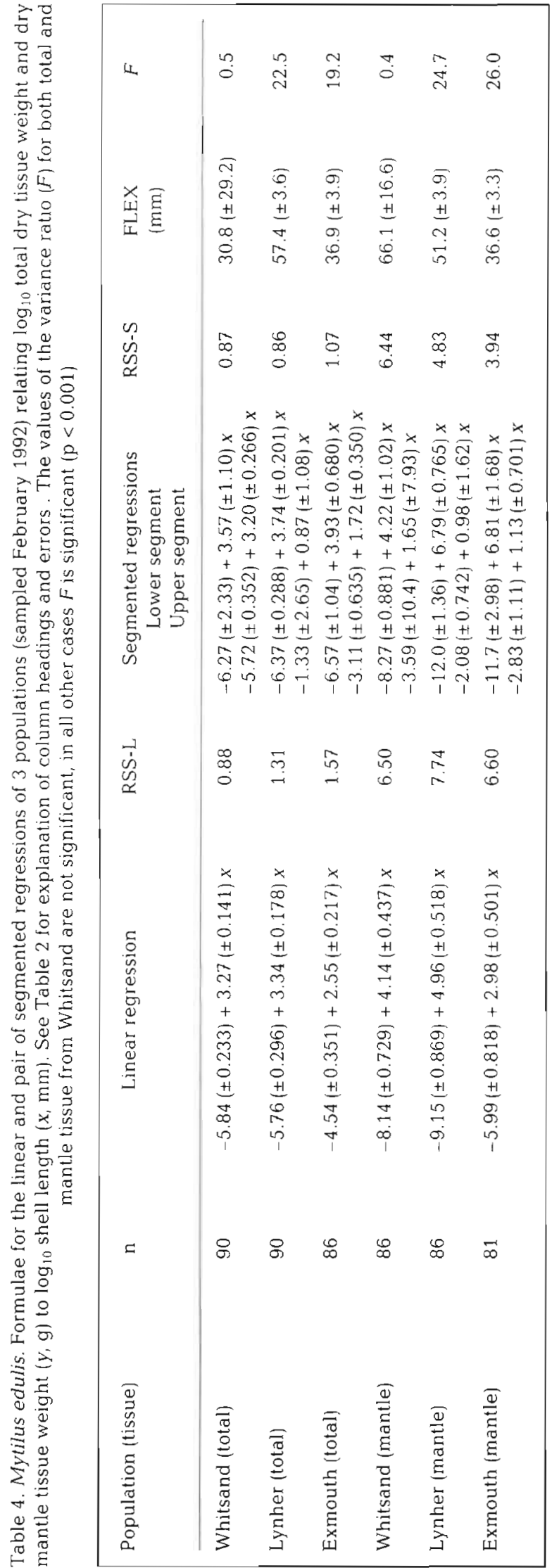


rate (energy loss); this results in a negative relationship between body weight and the feeding:metabolism ratio (Vahl 1973). So, under circumstances of poor food quality (e.g. during winter; Widdows et al. 1979), large mussels, with reduced but relatively high maintenance requirements (Bayne \& Newell 1983), may lose a relatively greater proportion of energy reserves than smaller mussels. This situation would then be reflected in a reduction in gamete production, which is known to occur even after short periods of starvation (Bayne et al. 1978, 1982, Pipe 1985).

Jørgensen (1976) suggests that these physiological processes are important in the determination of the final size of mussels. Whether they entirely explain the discontinuity in this data requires further study; but in the natural environment, particularly in dense sessile populations such as this Lynher population, other factors may interact with the processes outlined above. For example: intraspecific competition for food (Wildish 1977), availability of food (Fréchette \& Bourget 1985, Fréchette et al. 1989) and space (Hosomi 1987. Hughes \& Griffiths 1988), interference competition through the impairment of valve gape, thus reducing pumping rate (Famme et al. 1986, Fréchette et al. 1992), size-related aspects of mobility and byssus production (Allen et al. 1976), and the greater sensitivity to disturbance of feeding in larger mussels (Jørgensen 1976).

These nutritional aspects (see also Seed 1976, Seed \& Richardson 1990) are all important to growth rate and reproduction, and must contribute to the variability of the ultimate size of mussels in different populations. But, within the constraints of environment and genotype (Koehn \& Gaffney 1984), growth per se is dependent on age, and this factor may provide, as follows, an additional explanation.

In their investigation of this population, Bayne \& Worrall (1980) illustrate (their Fig. 3) a linear relationship between age and shell length for mussels between the ages of 2 and 5 yr [see also Gardner \& Thomas (1987) for another example of linearity between the ages of 1 and $3.5 \mathrm{yr}$ for a population exhibiting indeterminate growth]; thereafter there is a distinct reduction in shell growth as the plateau of the growth curve is approached. Using their von Bertalanfyy growth equation, the shell length at that age of $5 \mathrm{yr}$ is $52.4 \mathrm{~mm}$, and is remarkably similar to the length coordinate of the inflexion in the total $(50.3 \mathrm{~mm})$, mantle $(50.1 \mathrm{~mm})$ and remaining $(52.7 \mathrm{~mm})$ weights of tissues presented here (Table 2). This circumstantial evidence is of sufficient note to suggest that the age/size of $5 \mathrm{yr} /$ -52 $\mathrm{mm}$ may constitute a critical stage in the life history of these mussels: as growth ceases there is a change in the allometric relationship between shell length and the constituent tissues. This could repre- sent the onset of quantitative reproductive senescence (Peterson 1983), but it could also mark a change in reproductive strategy.

Such a strategy, to be consistent with the allometry, the stereological data and with the accepted view that reproductive output increases as growth declines isee above for references), requires evidence on the rate and quality of reproduction. The data presented here (Figs. 6\& 7) suggest that small and medium size ( $<5$ yr) mussels reproduce synchronously and intensively (i.e. mantles containing a large proportion of reproductive tissue), whilst large ( $>5 \mathrm{yr}$ ) individuals reproduce more frequently (perhaps twice yearly) and less intensively; further, more detailed studies are required on the interaction between size, age, availability of energy, its rate of allocation to growth, mainainance and reproduction and the timing and duration of the reproductive cycle

The examination of the weight-length relationships of the 3 populations sampled in February 1992 (Table 4), although representing only 1 sample, is instructive. The data from the Lynher population are consistent with the results of the 1983 to 1984 survey, with inflexions located at $57.4 \mathrm{~mm}$ (total tissue) and $51.2 \mathrm{~mm}$ (mantle). The other estuarine population (Exmouth) also exhibits an inflexion, but at a substantially different shell length $(36.9 \mathrm{~mm}$ for the total and $36.6 \mathrm{~mm}$ for the mantle). The age of this size of mussel, from this site, is approximately $4 \mathrm{yr}$ (S. McGrorty pers. comm.), suggesting that this change in allometry begins at an earlier age than those from the Lynher population. The mussels from the exposed rocky shore (Whitsand), on the other hand, show no inflexion in the data. Therefore, to be consistent with the above, it is suggested that these mussels may not reach the age at which this change occurs, and have indeterminate growth characteristics owing to factors (e.g. exposure to waves) not found in the estuarine environment.

Acknowledgements. I thank J. Widdows for encouragement and suggestions during the evolution of this paper I thank also R. K. Pipe for sample preparation and advice on producing the stereology data; $M$. Carr for statistical advice, R. I. Willows for graphics advice and together with $B$. L. Bayne and $P$. Donkin for constructive criticisms; also C. M. Worrall for permission to use his unpublished data.

\section{LITERATURE CITED}

Aldrich JC (1974) Allometric studies on energy relationships in the spider crab Libinia emarginata (Leach). Biol Bull $147: 257-273$

Allen JA, Cook M, Jackson D.J, Preston S, Worth EM (1976) Observations on the rate of production and mechanical properties of the byssus threads of Mytilus edulis $\mathrm{L}$. J mollusc Stud 42:279-289

Asmus H (1987) Secondary production of an intertıdal mussel 
bed community related to its storage and turnover compartments. Mar Ecol Prog Ser 39: 251-266

Bayne BL, Bubel A, Gabbott PA, Livingstone DR, Lowe DM, Moore MN (1982) Glycogen utilisation and gametogenesis in Mytilus edulis L. Mar Biol Lett 3: 89-105

Bayne BL, Holland DL, Moore MN, Lowe DM. Widdows J (1978) Further studies on the effects of stress in the adult on the eggs of Mytilus edulis. J mar biol Ass UK 58: 825-841

Bayne BL, Newell RC (1983) Physiological energetics of marine molluscs. In: Wilbur KM (ed) The Mollusca, Vol 4, Physiology, Part 1. Academic Press Inc, New York, p 407-515

Bayne BL, Salkeld PN, Worrall CM (1983) Reproductive effort and value in different populations of the marine mussel, Mytilus edulis L. Oecologia 59: 18-26

Bayne BL, Widdows J (1978) The physiological ecology of two populations of Mytilus edulis L. Oecologia 37: 137-162

Bayne BL, Widdows J, Thompson RJ (1976) Physiological integrations. In: Bayne BL (ed) Marine mussels: their ecology and physiology. Cambridge University Press, London, p 261-291

Bayne BL, Worrall CM (1980) Growth and production of mussels Mytilus edulis from two populations. Mar Ecol Prog Ser 3:317-328

Chappel R (1989) Fitting bent lines to data, with applications to allometry. J theor Biol 138:235-256

Dare PJ (1976) Settlement, growth and production of the mussel Mytilus edulis L., in Morecambe Bay, England. MAFF Fish Invest Ser II: $1-25$

Ebert TA, Russell MP (1994) Allometry and Model II non-linear regression. J theor Biol 168:367-372

Famme P, Riisgård HU, Jørgensen CB (1986) On direct measurement of pumping rates in the mussel Mytilus edulis Mar Biol 92: 323-327

Fréchette $M$, Aitken AE, Pagé L (1992) Interdependence of food and space limitation of a benthic suspension feeder: consequences for self-thinning relationships. Mar Ecol Prog Ser 83: 55-62

Fréchette $M$, and Bourget $E$ (1985) Energy flow between the pelagic and benthic zones: factors controlling particulate organic matter available to an intertidal mussel bed. Can $J$ Fish Aquat Sci 42: 1158-1165

Fréchette M, Butman CA, Rockwell Geyer W (1989) The importance of boundary-layer flows in supplying phytoplankton to the benthic suspension feeder, Mytilus edulis L. Limnol Oceanogr 34:19-36

Gabbott PA (1975) Storage cycles in marine bivalve molluscs: a hypothesis concerning the relationship between glycogen metabolism and gametogenesis. In: Barnes $\mathrm{H}$ (ed) Proc 9th Eur mar biol Symp, Aberdeen University Press, Aberdeen, p 191-211

Gardner JPA, Thomas MLH (1987) Growth, mortality and production of organic matter by a rocky intertidal population of Mytilus edulis in the Quoddy Region of the Bay of Fundy. Mar Ecol Prog Ser 39:31-36

Gould SJ (1966) Allometry and size in ontogeny and phylogeny. Biol Rev 41:587-640

Hilbish TJ (1986) Growth trajectories of shell and soft tissue in bivalves: seasonal variation in Mytilus edulis $\mathrm{L}$. J exp mar Biol Ecol 96:103-113

Hosomi A (1985) On several fundamental allometries of the mussel Mytilus galloprovincialis. Venus (Jap J Malacol) 44(3):172-182

Hosomi A (1987) On the density effect in populations of the mussel Mytilus galloprovincialis. Venus (Jap J Malacol) 46(2): $116-126$
Hughes RN, Griffiths CL (1988) Self-thinning in barnacles and mussels: the geometry of packing. Am Nat 132 $484-491$

Jorgensen CB (1976) Growth efficiencies and factors controlling size in some mytilid bivalves, especially Mytilus edulis: review and interpretation. Ophelia 15(2):175-192

Kautsky N (1982) Quantitative studies on gonad cycle, fecundity, reproductive output and recruitment in a Baltic Mytilus edulis population. Mar Biol 68: 143-160

Koehn RK, Gaffney PM (1984) Genetic heterozygosity and growth rate in Mytilus edulis. Mar Biol 82:1-7

Kuenzler EJ (1961) Structure and energy flow of a mussel population in a Georgia salt marsh. Limnol Oceanogr 6 191-204

LaBarbera M (1989) Analysing body size as a factor in ecology and evolution. A Rev Ecol Syst 20:97-117

Lowe DM, Moore MN, Bayne BL (1982) Aspects of gametogenesis in the marine mussel Mytilus edulis $\mathrm{L}$. J mar biol Ass UK 62:133-145

Lutz RA, Rhoads DC (1980) Growth patterns within the molluscan shell: an overview. In: Stehli FG (series ed) Topics in geobiology, Vol 1; Rhoads DC, Lutz RA (eds) Skeletal growth of aquatic organisms. Plenum Press, New York, p 203-254

McGrorty S, Goss-Custard JD (1991) Population dynamics of the mussel Mytilus edulis: spatial variation in age-class densities of an intertidal estuarine population along environmental gradients. Mar Ecol Prog Ser 73:191-202

Okamura B (1986) Group living and the effects of spatial position in aggregations of Mytilus edulis. Oecologia 69: $341-347$

Peterson CH (1983) A concept of quantitative reproductive senility: application to the hard clam, Mercenaria mercenaria (L.)? Oecologia 58:164-168

Pipe RK (1985) Seasonal cycles in and effects of starvation on egg development in Mytilus edulis. Mar Ecol Prog Ser 24: $121-128$

Rodhouse PG, Roden MP, Burnell GM, Hensey MP, McMahon T, Ottway B, Ryan TH (1984) Food resource, gametogenesis and growth of Mytilus edulis on the shore and in suspended culture: Killary Harbour, lreland. J mar biol Ass UK 64: 513-529

SAS Institute Inc (1985a) SAS user's guide: statistics, Version 5 edn. SA.S Institute, Inc, Cary, NC

SAS Institute Inc (1985b) SAS/GRAPH user's guide, Version 5 edn, SAS Institute, Inc, Cary, NC

Seed R (1973) Absolute and allometric growth in the mussel, Mytilus edulis L. (Mollusca, Bivalvia). Proc malac Soc Lond 40:343-357

Seed R (1976) Ecology. In: Bayne BL (ed) Marine mussels: their ecology and physiology. Cambridge University Press, London, p 13-65

Seed R, Richardson CA (1990) Mytilus growth and its environmental responsiveness. In: Stefano GB (ed) Neurobiology of Mytilus edulis. Manchester University Press, Manchester, p 1-37

Smith RJ (1980) Rethinking allometry. J theor Biol 87: 97-111

Sprung M (1983) Reproduction and fecundity of the mussel Mytilus edulis at Helgoland (North Sea). Helgoländer Meeresunters 36: 243-255

Teissier G (1960) Relative growth. In: Waterman TH (ed) The physiology of Crustacea, Vol I. Academic Press, New York, p 537-560

Theisen BF (1968) Growth and mortality of culture mussels in the Danish Wadden Sea. Meddr Danm Fisk Havunders NS $6: 47-78$

Thompson RJ (1979) Fecundity and reproductive effort in the 
blue mussel (Mytilus edulis), the sea urchin (Strongylocentrotus droebachiensis), and the snow crab (Chionoecetes opilio) from populations in Nova Scotia and Newfoundland. J Fish Res Bd Can 36(8):955-964

Thompson RJ (1984) Production, reproductive effort, reproductive value and reproductive cost in a population of the blue mussel Mytilus edulis from a subarctic environment. Mar Ecol Prog Ser 16:249-257

Thompson RJ, Ratcliffe NA, Bayne BL (1974) Effects of starvation on structure and function in the digestive gland of the mussel (Mytilus edulis L.). J mar biol Ass UK 54 $699-712$

This article was submitted to the editor
Vahl O (1973) Pumping and oxygen consumption rates of Mytilus edulis of different sizes. Ophelia 12:45-52

Vahl O (1985) Size specific reproductive effort in (Chlamys islandica): reproductive senility or stabilising selection? In: Gibbs PE (ed) Proc 19th Eur mar biol Symp, 16-21 Sept 1984. Cambridge University Press, Cambridge, p 521-527 Widdows J, Fieth P, Worrall CM (1979) Relationships between seston, available food and feeding activity in the common mussel Mytilus edulis. Mar Biol 50:195-207

Wildish DJ (1977) Factors controlling marine and estuarine sublittoral macrofauna. Helgoländer wiss Meeresunters $30: 445-454$

Manuscript first received: September 16, 1994

Revised version accepted: February 23, 1995 